\section{Children of Divorce}

The Divorce Reform Act 1969 came into force on New Year's Day. Irretrievable breakdown of marriage thus becomes the sole ground of divorce, a situation increasingly recognized and acted upon by some judges in the past few years. The number of divorces in the immediate future is expected to rise and may far exceed the 60,000 recorded in the post-war peak of 1947. In fact, the number has already more than doubled since the trough of 22,000 divorces and annulments in 1958. Of the 45,000 women divorced in 1968 more than 12,000 were childless, ${ }^{1}$ but the remainder had a total of about 60,000 children of all ages. No doubt great efforts are made by the High Court to safeguard the interests of these children, to secure financial provision for them, and to arrange for their welfare, but no court can compensate a child for absence of one of its parents.

Few medical and sociological reports in Britain have paid attention to the effect of divorce on the children of the marriage. This is in contrast to the swollen literature on the "broken-home" situation in general, its relation to neurosis and delinquency, and the many articles on death of a parent ${ }^{2} 3$ in childhood. As Lady Wootton has said," "The sociological study of divorce, apart from a few American investigations, has remained comparatively unfashionable." Divorce is far commoner in the United States. The number has doubled each year since 1940 and by 1967 had reached 523,000, involving 700,000 children under 18 each year.

The author of a recent paper, ${ }^{5} \mathrm{~J}$. F. McDermott studied the records of 1,487 children up to the age of 14 seen at a university psychiatric clinic in Michigan. He excluded 22 whose parents were separated but not divorced, and then compared the 116 children of divorced parents with the remainder. He found that, as compared with the remainder of the children, those with divorced parents were more often only children, had a shorter duration of symptoms, and that "acting out" and poor behaviour at school and at home predominated over neurotic symptoms. Delinquent and predelinquent behaviour and depression, both overt and masked, distinguished this group from the controls.

The second part of the paper is an impressionistic study from the case records of children directly involved in the divorce. McDermott found overt depressive symptoms in one-third of the patients and covert depression too-for example, accident proneness, lack of concern with safety, complaints of fatigue, and depression alternating with aggression. He found several children who regarded themselves quite unjustly as responsible for the divorce and blamed themselves. Quarrels between the parents over maintenance payments after the divorce often upset the child further, as did, of course, continuing battles over custody and visiting and the parents' continuing need to hurt each other. Problems of identification were encountered when children identified themselves with the missing parent or themselves ran away, and they did so too when the mother cast the child in the role of the missing husband.

As the author himself admits, this study has defects. It was retrospective; some important material was missing from the case records; and the controls often came from unstable families themselves. He utters cautions about generalizing from the findings in these sick children to other children of divorce who are not psychiatric patients. An earlier study by the same: author ${ }^{6}$ reports that 10 out of 16 ordinary nursery school children of divorced couples showed dramatic changes in behaviour at the time of divorce. Shock, anger, depression, denial, destructiveness, and regression were observed. Often this disturbance in the child led to inquiries that showed that the mother had concealed the fact of divorce from the schoolthough not from the child.

A further clue to the frequency of disturbance in the children of divorce appears in another American study. ${ }^{7}$ Of 148 consecutive divorces coming before a family court 105 involved children. Of these, $31 \%$ showed continuing strife between the partners about money, custody, and visiting. It is clear that in these cases the couples remained embattled and the children were used as pawns. Occasionally it was the children who were stirring up trouble in order to get their parents to become reunited. Divorce is only the culmination of a prolonged family upheaval, and the upheaval can continue long after the divorce. Indeed it sometimes seems to affect the next generation. McDermott's studies show clearly that the fact of physical separation from one parent, which is the usual consequence of divorce, imposes on children an acute extra stress. In an uncertain proportion of cases this stress leads to depression, grief reactions, "acting out" behaviour, and aberrations of identification.

It is sometimes thought better for a child to live with one divorced parent than with two unhappily married parents. The few studies mentioned here show that this comfortable doctrine of "get on or get out" needs looking at again. Perhaps the other stereotype, the wife who says that she will stick it out until the children are grown up, could be the wiser.

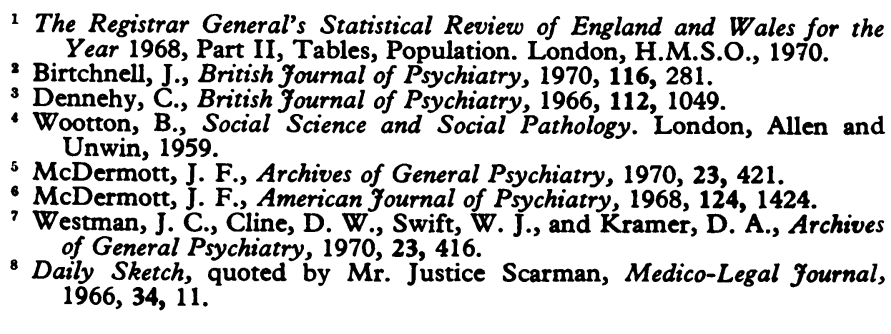

\section{Chlorpropamide in Diabetes Insipidus}

Hypofunction of endocrine glands is usually treated by replacement of the hormone. In some diseases, such as Addison's disease or hypothyroidism, giving the hormone by mouth is sufficient, while in others, such as diabetes mellitus, injections are necessary because of the protein nature of the hormone. Good results have also been obtained with substances which are not hormones but can nevertheless correct or ameliorate the endocrine hypofunction: vitamin D therapy in hypoparathyroidism and sulphonylureas in diabetes mellitus are two notable examples.

In the treatment of diabetes insipidus replacement therapy with vasopressin either by injection or as a snuff remains the mainstay of treatment. But over the last 30 years several substances with little or no chemical similarity to vasopressin have been reported to benefit patients with this disease. In 1932 , for instance, aminopyrine ${ }^{1}$ was shown to decrease the urine volume in patients with diabetes insipidus, but its toxic effects precluded a full assessment of its usefulness.

As a result of in vitro studies in which paracetamol was found to increase the flow of water across the bladder wall of 